\begin{tabular}{|l|}
\hline :مدذوف: role \\
\hline :محذوف: bio improving \\
\hline :محذوف: growth \\
\hline :مدذوف: grapevines \\
\hline
\end{tabular}

محذوف: Flame

محذوف: व

It is evident from the foregoing results that

(محذوف: (

\section{The Role of Bio-fertilization in Improving the Growth and Fruiting of Thompson Seedless Grapevines}

\author{
El-Salhy, A.M.; M.M. El-Akkad; Fatma El-Zahraa M. Gouda and Marwa \\ A.M. Gamea
}

Pomology Dept., Fac. Agric., Assiut Univ., Assiut, Egypt.

Received on: 20/7/2017

Abstract

This study was conducted during 2015 \& 2016 seasons, on 16 years old Thompson Seedless grapevines, grown on the experimental orchard of the Faculty of Agriculture, Assiut University to study the effect of bio-fertilization (nitrobine or EM) on vegetative growth, nutrient status, and fruiting of, Thompson Seedless grapevines. The experiment was arranged in a complete randomized block design with five treatments and three replications one vine per each.

The obtained results could be summarized as follow:

Using the recommended dose of nitrogen $(\mathrm{RDN})$ via 75 or $50 \%$ mineral plus 25 or $50 \%$ bio-form significantly increased, pruning wood weight, number of leaves/shoot and leaf area as well as leaf total chlorophyll and leaf nutrient composition compared to use $\mathrm{RDN}$ via mineral $\mathrm{N}$ fertilizer alone. No significant differences on these traits due to use $\mathrm{RDN}$ via $50 \%$ mineral plus either 12.5 or $37.5 \%$ of nitrobine or 37.5 or $12.5 \%$ effective microorganisms (EM) were noticed. All combined fertilization treatments significantly increased the yield and improved the cluster and berry traits compared to use RDN via mineral source only._It is evident from the forogoing results that double form $50 \%$ mineral plus either ( 37.5 and $12.5 \%$ nitrobine) or ( 12.5 or $37.5 \% \mathrm{EM})$ improved the vegetative growth, yield and berry quality. In addition, it minimized the production costs and reduced environmental pollution.

Keywords: Bio-fertilizers, Fruiting, Berry quality, Grapevines.

\section{Introduction}

Grape (Vitis vinifera, L.) is considered as one of the most popular and favorite fruit crops in the world. It reached about 192934 feddans, with a total annual production of 1596169 tons according to the statistics of M.A.L.R. (2014). The grapevines require adequate cultural practices, appropriate climatic and soil conditions. Fertilization is one of the most important management in improving the soil fertility and increase crop yield. Nitrogen has a pronounced role to improve production and fruit quality. This fact is fluctuated according to the side of the area, amount applied, the dose as well as the sources and time applied. The nitrogen fertilizer efficiency under field and surface irrigation conditions rarely exceeds $50 \%$ and it ranges between 30 and 40\% (Saharwat, 1979).

Nitrogen has many functions in plant life being part of proteins, an important constituent of protoplasm, responsible for biosynthesis of enzymes, amino acids, plant pigments and encouragement of cell division (Nijjar, 1985 and Mengel and Kirkby, 2001). The relationship between yield, fruit quality and health seems to be a complex and can be influenced by nitrogen fertilization (El- 
Salhy et al., 2013). Continuous use of chemical fertilization leads to the deterioration of soil characteristics and fertility and might lead to the accumulation of metals in plant tissues, affecting the fruit nutritional value and edibility. They not only have harmful effects on the environment but also they are a very great danger that harmful residues may remain in food (Bogatyre, 2000; Shimbio et al., 2001 and Keller, 2005).

Controlling chemical fertilization, especially $\mathrm{N}$ fertilizer is very important for reducing environmental pollution and obtaining safe produce. Using bio-fertilizers could relatively good method in this respect (ElHaddad et al., 1993; Verna, 1999; Ram Rao et al., 2007 and El-Salhy et al., 2011).

Applications of bio-fertilizers containing beneficial microorganisms instead of synthetic chemicals are known to improve plant growth through the supply of plant nutrients and may help to sustain environmental health and soil productivity. Nitrogen fixing cyanobacteria and effective microorganisms (EM) are used in order to improve the soil fertility, fertilizer efficiency and productivity of trees (Myint, 1999; Kannaiyan, 2002 and Ahmed et al., 2015). They are known to improve fixation of nutrients in the rhizosphere, produce growth stimulants for plants, improve soil stability, provide biological control, biodegrade substance, recycle nutrients, promote mycorrhiza symbiosis and develop bioremediation process in soil contaminated with toxic, xenobiotic and recalcitrant substances. Ad- ditionally, the use of bio-fertilizers can improve productivity per unit area in a relatively short time, consume smaller amounts of energy, mitigate contamination of soil and water, increase soil fertility, and promote antagonism and biological control of phytopathogenic organisms (Shimbio et al., 2001; Abdel-Hamid, 2002; Chirinos et al., 2006 and ElSalhy et al., 2006). Supplying the various grapevine cultivar with biofertilizers only or beside mineral-N source caused a pronounced increase in vegetative growth and nutritional status of vines, as well as in yield components, cluster traits and berry quality (Abdel-Hady, 2003; ElShenawy and Fayd, 2005; Abbas et al., 2006; Mostafa, 2008; AbdelMonem et al., 2008; Abada, 2009; ElSabagh et al, 2011; El-Salhy et al., 2011; Rabie and Negm, 2012; Masoud, 2012 and El-Salhy et al., 2017).

The aim of this study was to investigate the possibility of using biofertilization partially instead of completed mineral fertilizers on growth and fruiting of Thompson Seedless grapevines.

\section{Materials and Methods}

The present study was carried out during two successive seasons of 2015 and 2016 on Thompson Seedless grapevines. The vines were grown in the experimental vineyard of the Faculty of Agriculture, Assiut University, where the soil is clay. Some properties of the orchard soil were determined according to Wilde et al. (1985) and are present in Table (1). 
Table 1. Some physical and chemical properties of the soil of the experiment site.

:مدذوف: dates

محذوف: as a bio-fertilizers

محذوف: soil fertilization,

\begin{tabular}{|l|}
\hline محذوف: of \\
\hline محذوف: yeast \\
\hline $\begin{array}{l}\text { محذو: (240 g ammonium ni- } \\
\text { trate/vine/year) }\end{array}$ \\
\hline محذو: Some v \\
\hline
\end{tabular}

محذوف: leaf

محذوف: leaf

\begin{tabular}{|l|c|l|c|}
\hline \multicolumn{1}{|c|}{ Soil properties } & \multicolumn{1}{c|}{ Values } & \multicolumn{1}{c|}{ Soil properties } & Values \\
\hline Sand \% & 15.43 & Total N $(\%)$ & 0.17 \\
\hline Silt \% & 33.22 & Total $\mathrm{K}(\%)$ & 0.22 \\
\hline Clay \% & 51.35 & $\mathrm{NaHCO}_{3}$ extractable $\mathrm{P}(\mathrm{ppm})$ & 21.61 \\
\hline Texture & Clay & $\mathrm{NH}_{4} \mathrm{OAC}$-extractable K $(\mathrm{ppm})$ & 401.33 \\
\hline $\mathrm{CaCO}_{3}(\%)$ & 3.66 & DTPA extractable $\mathrm{Fe}(\mathrm{ppm})$ & 13.19 \\
\hline Organic matter $(\%)$ & 1.32 & DTPA extractable $\mathrm{Mn}(\mathrm{ppm})$ & 15.16 \\
\hline $\mathrm{pH}(1: 1$ suspension) & 8.10 & DTPA extractable $\mathrm{Zn}(\mathrm{ppm})$ & 2.35 \\
\hline $\mathrm{ECe}\left(\mathrm{dS} / \mathrm{m}^{-1}\right)$ & 2.69 & DTPA extractable $\mathrm{Cu}(\mathrm{ppm})$ & 2.11 \\
\hline
\end{tabular}

The vines were 16 years old at the starting of this experiment and spaced at $2 \times 2.5$ meters apart. The chosen vines were received the usual agriculture practices that are used in the vineyard including irrigation and pest control. The vines were trained according to the head training system and pruned during the second week of January.

The experiment included the following five treatments:

1- Application of the recommended dose of nitrogen (RDN), $80 \mathrm{~g}$ $\mathrm{N} /$ vine/year $(240 \mathrm{~g}$ ammonium nitrate) as $100 \%$ mineral $\mathrm{N}$ form $\left(\mathrm{T}_{1}\right)$.

2- Application of the $\mathrm{RDN}$ as $75 \%$ mineral plus $12.5 \%$ nitrobine and $12.5 \%$ effective microorganisms $(\mathrm{EM})$ as bio-fertilizers $\left(\mathrm{T}_{2}\right)$.

3- Application of the $\mathrm{RDN}$ as $50 \%$ mineral plus $25 \%$ nitrobine and $25 \%$ EM as bio-fertilizers $\left(\mathrm{T}_{3}\right)$.

4- Application of the RDN as $50 \%$ mineral plus $12.5 \%$ nitrobine and $37.5 \%$ EM as bio-fertilizers $\left(\mathrm{T}_{4}\right)$.

5- Application of the RDN as $50 \%$ mineral plus $37.5 \%$ nitrobine and $12.5 \% \mathrm{EM}$ as bio-fertilizers $\left(\mathrm{T}_{5}\right)$.

The experiment was set up as a complete randomized block design. Each treatment was replicated three times, one vine per each. The mineral nitrogen source was ammonium nitrate $(33.5 \% \mathrm{~N})$ and it was applied at three times: growth start, immediately after berry set and at two month later. Nitrobine and EM as bio-fertilizers were added in two equal batches at the growth start and one month later. Nitrobine is a bio-fertilizer which contains nitrogen fixing bacteria. Effective microorganisms (EM) contains a mixed of photosynthetic and lactic acid bacteria as well as actinomyces, yeasts and fungi.

The following parameters were determined to evaluate the effects of different fertilization treatments on growth, nutrient status, yield and berry quality.

\section{1-Vegetative growth Parameters:}

All vegetative growth traits i.e. main shoot thickness $(\mathrm{cm})$, number of leaves/ shoot, leaf area and total chlorophyll were measured in the middle of July.

Total chlorophyll content (\%) was determined by using (chlorophyll meter, SPAD-502 Konica Minolta).

The average leaf area $\left(\mathrm{cm}^{2}\right)$ : Twenty leaves from those opposite to basal clusters were measured according to the following equation that was reported by Ahmed and Morsy (1999)

Leaf area $=0.56(0.79 \times$ w2 $)+$ 20.01 , where, $\mathrm{w}=$ the maximum leaf width. 
In addition, weight of pruning wood was calculated immediately after pruning.

\section{2- Leaf nutritional status:}

Samples of 30 leaves for each محذوف: the top of shoots محذوف: length محذوف: and محذوف: and

محذوف: was recorded

محذوف: At harvest time, $t$ محذوف: the yield of replication were collected from the first full mature leaves from shoots top in mid of July and leaf petioles were separated from the blades. The petioles were washed with tap water, distilled water, air-dried, oven-dried at $70^{\circ} \mathrm{C}$ to constant weight, then ground in a stainless steel mill. Wet digestion was done by using concentrated sulphoric acid and hydrogen peroxide for overnight. Percentages of $\mathrm{N}, \mathrm{P}$ and $\mathrm{K}$ (on dry weight basis) were determined in the digestion according to Wilde et al. (1985).

\section{3- Yield:}

At harvest date (mid of July), the yield per vine in terms of weight $(\mathrm{kg})$ and number of clusters per vine was recorded.

4- Cluster and berry characteristic: Two clusters were randomly taken from each vine to determine the cluster and berry traits such as cluster weight and cluster compactness coefficient. Berry quality such as berry weight and dimension as well as reducing sugar percentages, total soluble solids and total acidity (expressed as gm tartaric acid per $100 \mathrm{ml}$ juice), berry properties were evaluated according to A.O.A.C. methods (1985). All the obtained data were tabulated and analyzed according to Gomez and Gomez, (1984) using L.S.D. test for distinguishing the significance differences between various treatment means according to Steel and Torrie (1980).

\section{Results \\ 1- Vegetative growth and leaf nutritional status:}

Data presented in Tables $(2,3$ \& 4) showed the effect of nitrobine and EM as a bio-fertilization in comparison with mineral $\mathrm{N}$ on shoot thickness, pruning wood weight, number of leaves/shoot, leaf area and total chlorophyll as well as leaf $\overline{\mathrm{N}, \mathrm{P}}$ $\& \mathrm{~K} \%$ of Thompson Seedless grapevines during 2015 and 2016 seasons. It is obvious from the data that the results took similar trend during the two studied seasons.

In a general view, data in prementioned tables showed that the application of the required $\mathrm{N}$ through using 75 or $50 \%$ of the recommended dose of nitrogen (RDN) as mineral $\mathrm{N}$ along with using 25 or $50 \%$ as biofertilization significantly increased such traits compared to using RDN only as a mineral $\mathrm{N}$ fertilizer. The promotion on such growth traits was associated with increasing the applied level of the bioform from 25 to $50 \%$. The maximum values of shoot thickness, pruning wood weight and leaf traits were recorded on the vines that were fertilized with the required $\mathrm{N}$ as $50 \%$ in a mineral $\mathrm{N}$ along $37.5 \%$ nitrobine plus $12.5 \%$ EM. On other hand, the lowest values of the growth traits as well as total chlorophyll, N, $\mathrm{P}$ and $\mathrm{K}$ contents were recorded for the vines that were treated with $100 \%$ mineral $\mathrm{N}$ (check treatment, $\mathrm{T}_{1}$ ). No significant differences were found due to fertilize by either $50 \%$ mineral-N plus $12.5 \%$ nitrobine and $37.5 \%$ EM $\left(\mathrm{T}_{4}\right)$ or $50 \%$ mineral-N plus $37.5 \%$ nitrobine and $12.5 \% \mathrm{EM}$ $\left(\mathrm{T}_{5}\right)$. The highest pruning wood weight $(1.76 \mathrm{~kg} / \mathrm{vine})$, leaf area 
محذوف: check treatment,

محذوف: as well as decreased the opportunity of the environmental pollution
(193.8 $\left.\mathrm{cm}^{2}\right), \quad$ total chlorophyll (49.69\%) and leaf $\mathrm{N}(1.75 \%$ as an av. of the two studied seasons) were obtained due to use $50 \%$ mineral-N plus $37.5 \%$ nitrobine and $12.5 \% \mathrm{EM}\left(\mathrm{T}_{5}\right)$. On other hand, the lowest values of these traits were recorded on the vines treated with $100 \%$ mineral-N $\left(\mathrm{T}_{1}\right)$. Then, the increment percentage of pruning wood weight, leaf area, total chlorophyll and leaf $\mathrm{N} \%$ were (9.31, 8.09, 1.96 and $20.69 \%$ as an av. the two studied seasons) due to use 50\% mineral-N along 37.5\% nitrobine and $12.5 \% \mathrm{EM}\left(\mathrm{T}_{5}\right)$ compared to the check treatment $\left(\mathrm{T}_{1}\right)$, respectively.

Therefore, $\mathrm{N}$ fertilization with bio-sources as a partial substitute for mineral ones significantly increased the total leaf surface area, nutritional status and vegetative growth of vines,

Table 2. Effect of bio-fertilization on shoot thickness and pruning wood weight of Thompson Seedless grapevines during 2015 \& 2016 seasons.

\begin{tabular}{|l|c|c|c|c|c|c|}
\hline \multirow{2}{*}{ Charac. } & \multicolumn{3}{|c|}{$\begin{array}{c}\text { Thickness of the } \\
\text { shoot }(\mathbf{c m})\end{array}$} & \multicolumn{3}{c|}{$\begin{array}{c}\text { Pruning wood } \\
\text { weight (kg/vine) }\end{array}$} \\
\cline { 2 - 7 } Treatments & $\mathbf{2 0 1 5}$ & $\mathbf{2 0 1 6}$ & Mean & $\mathbf{2 0 1 5}$ & $\mathbf{2 0 1 6}$ & Mean \\
\hline$-100 \%$ mineral N $\left(\mathrm{RDN}, \mathrm{T}_{\mathbf{1}}\right)$ & 0.82 & 0.85 & 0.84 & 1.51 & 1.71 & 1.61 \\
\hline$-75 \%$ min. $+12.5 \%$ nitrobine $+12.5 \% \mathrm{EM}\left(\mathrm{T}_{\mathbf{2}}\right)$ & 0.88 & 0.92 & 0.90 & 1.59 & 1.82 & 1.71 \\
\hline$-50 \%$ min. $+25 \%$ nitrobine $+25 \% \mathrm{EM}\left(\mathrm{T}_{\mathbf{3}}\right)$ & 0.90 & 0.93 & 0.91 & 1.62 & 1.85 & 1.74 \\
\hline$-50 \%$ min. $+12.5 \%$ nitrobine $+37.5 \% \mathrm{EM}\left(\mathrm{T}_{\mathbf{4}}\right)$ & 0.88 & 0.92 & 0.90 & 1.60 & 1.83 & 1.72 \\
\hline$-50 \%$ min. $+37.5 \%$ nitrobine $+12.5 \% \mathrm{EM}\left(\mathrm{T}_{\mathbf{5}}\right)$ & 0.91 & 0.94 & 0.93 & 1.64 & 1.87 & 1.76 \\
\hline LSD 5\% & $\mathbf{0 . 0 4}$ & $\mathbf{0 . 0 5}$ & & $\mathbf{0 . 0 6}$ & $\mathbf{0 . 0 9}$ & \\
\hline
\end{tabular}

Table 3. Effect of bio-fertilization on some leaf traits of Thompson Seedless grapevines during 2015 \& 2016 seasons.

\begin{tabular}{|c|c|c|c|c|c|c|c|c|c|}
\hline \multirow{2}{*}{$\begin{array}{c}\text { Charac. } \\
\text { Treatments }\end{array}$} & \multicolumn{3}{|c|}{\begin{tabular}{c} 
Number of leaves/shoot \\
\cline { 2 - 10 }
\end{tabular}} & \multicolumn{3}{c|}{ Leaf area $\mathbf{( c m}^{\mathbf{2}}$} & \multicolumn{3}{c|}{$\begin{array}{c}\text { Total chlorophyll } \\
\text { SPAD value }\end{array}$} \\
\cline { 2 - 11 } & $\mathbf{2 0 1 5}$ & $\mathbf{2 0 1 6}$ & Mean & $\mathbf{2 0 1 5}$ & $\mathbf{2 0 1 6}$ & Mean & $\mathbf{2 0 1 5}$ & $\mathbf{2 0 1 6}$ & Mean \\
\hline $\mathrm{T}_{\mathbf{1}}$ & 19.30 & 21.46 & 20.38 & 184.8 & 173.7 & 179.3 & 43.20 & 45.19 & 44.23 \\
\hline $\mathrm{T}_{\mathbf{2}}$ & 20.81 & 23.28 & 22.05 & 193.4 & 183.9 & 188.7 & 46.68 & 49.11 & 47.90 \\
\hline $\mathrm{T}_{\mathbf{3}}$ & 21.12 & 23.74 & 22.43 & 196.5 & 186.7 & 191.6 & 47.41 & 49.80 & 48.61 \\
\hline $\mathrm{T}_{\mathbf{4}}$ & 21.39 & 24.21 & 22.80 & 194.8 & 185.4 & 190.1 & 47.95 & 50.33 & 49.14 \\
\hline $\mathrm{T}_{\mathbf{5}}$ & 21.85 & 24.76 & 23.31 & 198.7 & 188.8 & 193.8 & 48.81 & 51.12 & 49.96 \\
\hline LSD 5\% & $\mathbf{1 . 2 1}$ & $\mathbf{1 . 6 3}$ & & $\mathbf{7 . 8 1}$ & $\mathbf{8 . 3 2}$ & & $\mathbf{1 . 9 3}$ & $\mathbf{2 . 2 3}$ & \\
\hline
\end{tabular}

Table 4. Effect of bio-fertilization on leaf $N, P$ and $K$ content of Thompson Seedless grapevines during 2015 \& 2016 seasons.

\begin{tabular}{|c|c|c|c|c|c|c|c|c|c|}
\hline \multirow{2}{*}{ Charac. } & \multicolumn{3}{|c|}{ Leaf content of N\% } & \multicolumn{3}{c|}{ Leaf content of P\% } & \multicolumn{3}{|c|}{ Leaf content of K\% } \\
\cline { 2 - 11 } Treatments & $\mathbf{2 0 1 5}$ & $\mathbf{2 0 1 6}$ & Mean & $\mathbf{2 0 1 5}$ & $\mathbf{2 0 1 6}$ & Mean & $\mathbf{2 0 1 5}$ & $\mathbf{2 0 1 6}$ & Mean \\
\hline $\mathrm{T}_{\mathbf{1}}$ & 1.44 & 1.46 & 1.45 & 0.201 & 0.208 & 0.205 & 0.74 & 0.78 & 0.76 \\
\hline $\mathrm{T}_{\mathbf{2}}$ & 1.59 & 1.64 & 1.62 & 0.227 & 0.234 & 0.231 & 0.80 & 0.86 & 0.83 \\
\hline $\mathrm{T}_{\mathbf{3}}$ & 1.61 & 1.66 & 1.64 & 0.246 & 0.249 & 0.248 & 0.83 & 0.88 & 0.86 \\
\hline $\mathrm{T}_{\mathbf{4}}$ & 1.68 & 1.74 & 1.71 & 0.243 & 0.250 & 0.247 & 0.86 & 0.92 & 0.89 \\
\hline $\mathrm{T}_{\mathbf{5}}$ & 1.72 & 1.78 & 1.75 & 0.267 & 0.271 & 0.269 & 0.87 & 0.94 & 0.91 \\
\hline LSD 5\% & $\mathbf{0 . 0 7}$ & $\mathbf{0 . 0 8}$ & & $\mathbf{0 . 0 1 6}$ & $\mathbf{0 . 0 1 3}$ & & $\mathbf{0 . 0 5}$ & $\mathbf{0 . 0 7}$ & \\
\hline
\end{tabular}


محذوف: effective microorganisms ( (محذوف: ),

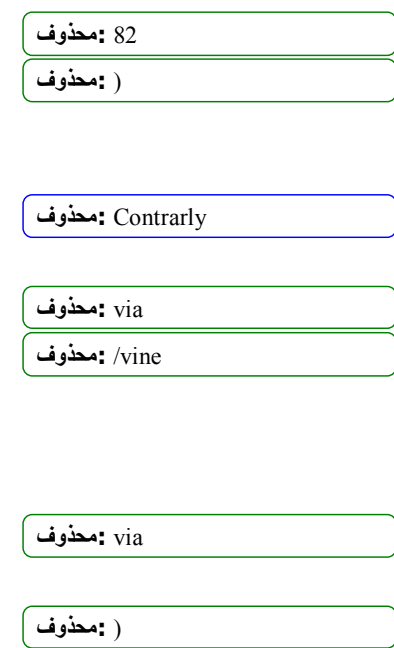

2- Yield and cluster characteristics:

Data presented in Tables $(5 \&$

6) showed that the number of clusters per vine on 2015 season did not alter with varying the fertilization treatments. On the other studied season, using nitrogen fertilization as double form (mineral-plus bio) significantly increased the cluster numbers/vine compared to application of $\mathrm{N}$ as $100 \%$ mineral fertilization. Double form significantly caused a remarkable promotion on cluster weight, yield/vine and compactness coefficient of cluster compared to using RDN mineral source only. Moreover, fertilized by combined forms gave the highest values of these traits and least values of compactness coefficient comparing with other fertilization treatment. The highest yield components and least values of cluster compactness coefficient were detected due to fertilize by $50 \%$ mineral-N plus $37.5 \%$ nitrobine and $12.5 \% \mathrm{EM}$ $\left(\mathrm{T}_{5}\right)$. The obtained highest values of cluster weight was $(387.6 \mathrm{~g})$ and yield/vine $(10.29 \mathrm{~kg})$ and least cluster compactness coefficient $(9.83)$ as an av. the two studied seasons due to fertilize by $50 \%$ mineral-N plus $37.5 \%$ nitrobine and $12.5 \% \mathrm{EM}\left(\mathrm{T}_{5}\right)$, respectively. Contrarily, these values on check vines were $(327.7 \mathrm{~g})$ and $(8.21 \mathrm{~kg})$ and (10.44), respectively. Hence the corresponding increment percentages for these traits over check treatment were $(18.28 \%)$ and $(25.33 \%)$ as well as the decrement percentage of cluster compactness coefficient was $(5.48 \%)$ as an av. the two studied seasons, respectively.

In general, it could be concluded that combined the biofertilization with mineral-N fertilization had positive effects on productivity of Thompson seedless grapevines.

Table 5. Effect of bio-fertilization on number of clusters, yield (kg/vine) and cluster weight of Thompson Seedless grapevines during 2015 \& 2016 seasons.

\begin{tabular}{|c|c|c|c|c|c|c|c|c|c|}
\hline \multirow{2}{*}{ Charac. } & \multicolumn{3}{|c|}{$\begin{array}{c}\text { Number of } \\
\text { cluster/vine }\end{array}$} & \multicolumn{3}{c|}{$\begin{array}{c}\text { Cluster weight } \\
\text { (g) }\end{array}$} & \multicolumn{3}{c|}{$\begin{array}{c}\text { Yield } \\
\text { (kg/vine) }\end{array}$} \\
\cline { 2 - 10 } Treatments & $\mathbf{2 0 1 5}$ & $\mathbf{2 0 1 6}$ & Mean & $\mathbf{2 0 1 5}$ & $\mathbf{2 0 1 6}$ & Mean & $\mathbf{2 0 1 5}$ & $\mathbf{2 0 1 6}$ & Mean \\
\hline $\mathrm{T}_{\mathbf{1}}$ & 25.1 & 24.5 & 24.8 & 315.5 & 338.8 & 327.7 & 8.10 & 8.31 & 8.21 \\
\hline $\mathrm{T}_{\mathbf{2}}$ & 25.6 & 26.7 & 26.2 & 348.3 & 368.5 & 358.4 & 8.98 & 9.82 & 9.40 \\
\hline $\mathrm{T}_{\mathbf{3}}$ & 24.9 & 27.5 & 26.2 & 360.9 & 379.2 & 370.1 & 8.95 & 10.35 & 9.65 \\
\hline $\mathrm{T}_{\mathbf{4}}$ & 25.6 & 27.8 & 26.7 & 366.8 & 388.1 & 377.5 & 9.36 & 10.78 & 10.07 \\
\hline $\mathrm{T}_{\mathbf{5}}$ & 24.8 & 28.3 & 26.6 & 378.4 & 396.8 & 387.6 & 9.37 & 11.20 & 10.29 \\
\hline LSD 5\% & N.S. & $\mathbf{1 . 3 5}$ & & $\mathbf{1 6 . 9 1}$ & $\mathbf{2 3 . 6 6}$ & & $\mathbf{0 . 6 3}$ & $\mathbf{0 . 7 8}$ & \\
\hline
\end{tabular}

Table 6. Effect of bio-fertilization on cluster characteristics of Thompson Seedless grapevines during 2015 \& 2016 seasons.

\begin{tabular}{|c|c|c|c|c|c|c|c|c|c|}
\hline \multirow{2}{*}{ Treatments } & \multicolumn{3}{|c|}{$\begin{array}{c}\text { Number of } \\
\text { berry/cluster }\end{array}$} & \multicolumn{3}{|c|}{ Cluster length (cm) } & \multicolumn{3}{|c|}{$\begin{array}{l}\text { Cluster compactness } \\
\text { coefficient }\end{array}$} \\
\hline & 2015 & 2016 & Mean & 2015 & 2016 & Mean & 2015 & 2016 & Mean \\
\hline $\mathrm{T}_{1}$ & 223.8 & 225.9 & 222.7 & 21. & 21 & 21.6 & 10.27 & 10.61 & 10.44 \\
\hline $\mathrm{T}_{2}$ & 231.8 & 237.0 & 234.4 & 23.4 & 23.2 & 23. & 9.87 & 10.22 & 10.05 \\
\hline$T_{3}$ & 231.9 & 237.8 & 234.9 & 24.1 & 23.5 & 23.8 & 9.62 & 10.13 & 9.88 \\
\hline $\mathrm{T}_{4}$ & & 238 & 235 & & & & 9.7 & 10 & 10.00 \\
\hline$T_{5}$ & 234.0 & 239.6 & 236.8 & 24. & 23 & 24.1 & 9.63 & 10.03 & 9.83 \\
\hline LSD 5\% & 6.36 & 8.63 & & 1.08 & 1.15 & & 0.35 & 0.31 & \\
\hline
\end{tabular}




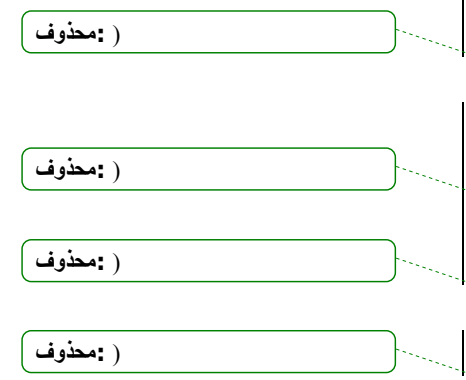

(محذوف: )

محذوف: pack able

\section{3- Berry quality:}

It can be concluded from data in Tables $(7 \& 8)$ that bio-fertilization in combination with mineral-N significantly increased the weight and size of berry compared to use mineral only. The heaviest berry weight was recorded on vines that received the RDN via two forms, $\mathrm{T}_{5}(1.54 \mathrm{~g})$ as an av. of the two studied seasons, again, the lightest berry weight was found on vines that received the RDN via $100 \%$ mineral-N (1.36 g as an av. of the two studied seasons, Hence the increment percentage of berry weight due such treatments over check treatments $\mathrm{T}_{1}$ was $(13.24 \%)$.

The increase in berry weight and size is an important target as grapes quality due to the increase in berry weight and size result in an increase in packable yield. Moreover, all fertilization applications which include mineral and bio- $\mathrm{N}$ forms significantly improved the chemical constituents of berry juice in term of increased the total soluble solids and reducing sugars and decreased the total acidity compared to use mineral$\mathrm{N}$ only. Furthermore, vines fertilized double forms $\left(\mathrm{T}_{5}\right)$ recorded the maximum values of these traits compared to other fertilization treatments. The highest total soluble solids and reducing sugars contents obtained on vines fertilized with $\left(\mathrm{T}_{5}\right)$, were $(22.4 \%)$ and $(15.52 \%)$ as an av. of the two studied seasons. Contrary, the least values of these traits were recorded on vines that fertilization by control $\left(T_{1}\right)$ which gave $(19.7 \%)$ and $(13.86 \%)$ as an av. of the two studied seasons, respectively. Hence, the increment percentage of these attributes due to using fertilization via the double forms $\left(T_{5}\right)$ over the check treatment, $\quad\left(\mathrm{T}_{1}\right)$ attained $(13.71 \% \quad \&$ $11.94 \%$ ), respectively. Also, such amending induce decrement percentage in total acidity attained (17.67) as an av. of the two studied seasons, respectively.

On the account of the present results, it could be concluded that replacing $50 \%$ of nitrogen requirements of vines by bio-form improved the growth and nutritional status, as well as, yield, cluster attributes and berry quality of Thompson Seedless grapevines under the circumstances of this experiment.
محذوف: On the account of the present results it could be concluded that replacing $50 \%$ of nitrogen requirements of vine by bio-form improved the growth and nutritional status as well as, yield, cluster attributes and berry quality of grapevines.
Table 7. Effect of bio-fertilization on some berry traits of Thompson Seedless grapes during $2015 \& 2016$ seasons.

\begin{tabular}{|c|c|c|c|c|c|c|c|c|c|}
\hline \multirow{2}{*}{ Charac. } & \multicolumn{3}{|c|}{ Berry weight (g) } & \multicolumn{3}{c|}{ Berry length (cm) } & \multicolumn{3}{c|}{ Berry diameter (cm) } \\
\cline { 2 - 11 } Treatments & $\mathbf{2 0 1 5}$ & $\mathbf{2 0 1 6}$ & Mean & $\mathbf{2 0 1 5}$ & $\mathbf{2 0 1 6}$ & Mean & $\mathbf{2 0 1 5}$ & $\mathbf{2 0 1 6}$ & Mean \\
\hline $\mathrm{T}_{\mathbf{1}}$ & 1.34 & 1.38 & 1.36 & 13.3 & 13.7 & 13.5 & 11.8 & 12.1 & 12.0 \\
\hline $\mathrm{T}_{\mathbf{2}}$ & 1.42 & 1.46 & 1.44 & 14.0 & 14.5 & 14.3 & 12.5 & 12.8 & 12.7 \\
\hline $\mathrm{T}_{\mathbf{3}}$ & 1.46 & 1.50 & 1.43 & 14.5 & 14.8 & 14.7 & 12.8 & 13.2 & 13.0 \\
\hline $\mathrm{T}_{\mathbf{4}}$ & 1.48 & 1.53 & 1.51 & 14.6 & 15.1 & 14.9 & 13.1 & 13.5 & 13.3 \\
\hline $\mathrm{T}_{\mathbf{5}}$ & 1.52 & 1.55 & 1.54 & 15.1 & 15.3 & 15.2 & 13.5 & 13.6 & 13.6 \\
\hline LSD 5\% & $\mathbf{0 . 0 7}$ & $\mathbf{0 . 0 6}$ & & $\mathbf{0 . 6 8}$ & $\mathbf{0 . 7 5}$ & & $\mathbf{0 . 5 3}$ & $\mathbf{0 . 4 6}$ & \\
\hline
\end{tabular}


Table 8. Effect of bio-fertilization on some chemical constituents of Thompson Seedless grapes during 2015 \& 2016 seasons.

\begin{tabular}{|c|c|c|c|c|c|c|c|c|c|}
\hline \multirow{2}{*}{ Charac. } & \multicolumn{3}{|c|}{ TSS \% } & \multicolumn{3}{c|}{ Reducing sugar \% } & \multicolumn{3}{c|}{ Titratable acidity \% } \\
\cline { 2 - 11 } Treatments & $\mathbf{2 0 1 5}$ & $\mathbf{2 0 1 6}$ & Mean & $\mathbf{2 0 1 5}$ & $\mathbf{2 0 1 6}$ & Mean & $\mathbf{2 0 1 5}$ & $\mathbf{2 0 1 6}$ & Mean \\
\hline $\mathrm{T}_{\mathbf{1}}$ & 18.6 & 20.8 & 19.7 & 13.49 & 14.23 & 13.86 & 0.521 & 0.543 & 0.532 \\
\hline $\mathrm{T}_{\mathbf{2}}$ & 19.5 & 21.6 & 20.6 & 14.08 & 14.81 & 14.45 & 0.478 & 0.502 & 0.490 \\
\hline $\mathrm{T}_{\mathbf{3}}$ & 20.6 & 22.5 & 21.6 & 14.84 & 15.31 & 15.08 & 0.446 & 0.468 & 0.457 \\
\hline $\mathrm{T}_{\mathbf{4}}$ & 21.1 & 22.9 & 22.0 & 15.25 & 15.50 & 15.38 & 0.454 & 0.475 & 0.465 \\
\hline $\mathrm{T}_{\mathbf{5}}$ & 21.4 & 23.3 & 22.4 & 15.39 & 15.64 & 15.52 & 0.427 & 0.448 & 0.438 \\
\hline LSD 5\% & $\mathbf{0 . 6 8}$ & $\mathbf{0 . 7 4}$ & & $\mathbf{0 . 4 5}$ & $\mathbf{0 . 5 2}$ & & $\mathbf{0 . 0 2 8}$ & $\mathbf{0 . 0 2 4}$ & \\
\hline
\end{tabular}

\section{Discussion:}

Bio-fertilization has an important impact on biological, physical and chemical soil properties (Kannaiyan, 2002 and El-Salhy et al., 2006).

The role of bio-fertilization on facilitating the fixation of atmospheric $\mathrm{N}$ as well as activating the availability uptake and translocation of most nutrients, that accelerating carbohydrate and protein synthesis and movement which aid to encouraging cell division and the development of meristematic tissues. Moreover, it enhancing the resistance of plants to root diseases and controlling vegetative growth of trees, then, improving its productivity (Gaur et al., 1980 Suba Rao, 1984 and Elsalhy et al., 2006). In addition, the effect of bio-fertilizer on activating the synthesis of total carbohydrates and proteins which enhances cell division and enlargement leading to improving the vine growth and nutritional status and maintaining a good balance between total carbohydrates and nitrogen in favor of improving bud burst and fertility coefficient that lead to an increase of cluster number per vine, hence the yield was increased and hastened the maturation and improved berry quality. These results of the present investigation agree with those of Abdel-Hamid (2002), AbdelHady (2003), El-Shenawy and Fayed
(2005), Abbas et al. (2006), El-Salhy et al. (2006), Mostafa (2008), AbdelMonem et al. (2008), Hegab et al. (2010), El-Sabagh et al. (2011), ElSalhy et al. (2011), Masoud (2012), El-Salhy et al. (2013), Ahmed et al. (2015) and El-Salhy et al. (2017). They concluded that application $\mathrm{N}$ via mineral and bio form was improved the growth aspects, yield and berry quality of grapevines.

\section{Conclusion:}

So it could be concluded that replacing $50 \%$ of nitrogen requirements for grapevines by biofertilization, are sufficient to improve nutritional status of grapevines and gave a suitable yield with high cluster and berry traits. In addition, it minimized the production costs and the environmental pollution which could be occurred by excess of chemical fertilizers.

\section{References}

A.O.A.C. 1985. Association of Official Agricultural Chemists, Official Methods of Analysis A.O.A.C. Benjamin Franklin Station, Washington, D.C.M.S.A. pp: 440-512.

Abada, M.A. 2009. Reducing the amount of inorganic-N fertilizers in Superior grape vineyard by using organic and bio-fertilizers and humic acid. Egypt. J. Agric. Res., 87 (1): 17-34.

Abbas, E.S.; S.A. Bondok and M.H. Rizk. 2006. Effect of bio and ni- 
محذوف: El-Mogy, M.M.; A.H. Omar and S.A. Gaser, Aisha. 1998. Effect of yeast application on bud fertility physical, chemical properties, vegetative growth and yield of Thompson seedless grapevine. J. Agric. Sci. Mansoura Univ., 28 (8): 3879-3886.

:محذوف: Abdelaal, A.H.M.; F.F Ahmed; M.F. Ebraheim and A.M. Abdel-Kareem. 2013. The beneficial effects of some humic acid, EM1 and weed control treatments on fruiting of Superior grapevines.
محذوف: Annual Reports of Statistics Institute and Agricultural Economic Dept., Ministry of Agric., Egypt, 2014.
محذوف: Esmaeil, F.H.; M.T. Wahdan and A.F. El-Sheikh. 2003. Response of Thompson Seedless and Roumi Red grape cultivars to foliar sprays with yeast extract and $\mathrm{GA}_{3}$. J. Agric. Sci., Mansoura Univ., 28 (8): 6321-6334. Gaser, Aisha, S.A.; A. El-Helw, Hanna and M.A. Abd El-Wahab. 2006. Effect of yeast doses and time of application on growth, yield and fruit quality of Flame seedless grapevines. Egypt. J. of Appl. Sci., 21 (8B): 661-681. trogen mineral fertilizers on growth and berry quality of Ruby seedless grapevines. J._Agric. Sci. Mansoura, 31(7): 4565-4577.

Abdel-Hady, A.M. 2003. Response of Flame seedless vines to application of some bio-fertilizers. Minia J. Agric. Res. \& Develop, 23(4): 667-680.

Abdel-Hamid, S.Y. 2002. Effect of biofertilizer on yield and berry quality of grapevines. M.Sc. thesis, Fac. Agric., Mansoura Univ., Egypt.

Abdel-Monem, E.A.A.; M.A.S. Saleh and E.A.M. Mostafa. 2008. Minimizing the quantity of mineral nitrogen fertilizers on grapevine by using humic acid, organic and biofertilizers. Res. of Agric. and Biol. Sci., 4 (1): 46-50.

Ahmed, F.F. and M.H. Morsy. 1999. A new method for measuring leaf area in different fruit crops. Minia J. of Agric. Res. \& Develop., 19: 97-105.

Ahmed, F.F.; A.H.M. Abdelaal; S.M.A. El-Masry and S.M.M. Hassan. 2015. Using some organic manures and EM a partial replacement of mineral-N fertilizers in Superior vineyards. World Rural Observations, 7 (3): 76-84.

Bogatyre, A.N. 2000. What are we do to eat or how to live longer? Pishchevaya Promyshlemost, 7: 34-35. (C.f.CAB).

Chirinos, J.; A. Leal and J. Montilla. 2006. Use alternative biological inputs for sustainable agriculture in the south of Anzaatequi state. Applied and Inter disciplinary Science, Biotechnology. Digital Magazine Ceniap Today, 11: 1-7.

El-Haddad, M.E.; Y.Z. Ishac and M.L. Mostafa. 1993. The role of biofertilizers in reducing agricultural costs, decreasing environmental pollution and raising crop yield.
Arab Univ. J. of Agric. Sci. Ain Shams Univ. Cairo, 1(1): 147-195.

El-Sabagh, A.S.; F.M. El-Morsy and A.R. Farag. 2011. Effect of biofertilizers as a partial substitute for nitrogen on vegetative growth, yield, fruit quality and leaf mineral content of two seedless grape cultivars. 1- Vegetative growth and yield. J. of Horti. Sci. \& Ornam. Plants, 3 (2): 166-175.

El-Salhy, A.M.; H.A. Abdel-Galil; R.A. Ibrahim; A.Y. Halim and M.K. Sayed. 2017. Effect of yeast and bio-power on growth and fruiting of Flame Seedless grapevines. Assiut J. Agric. Sci., 48 (1-1): 191201.

El-Salhy, A.M.; H.M. Mazrouk and M.M. El-Akkad. 2006. Biofertilization and elemental sulphur effects on growth and fruiting of King's Ruby and Roomy grapevines. Egyptian J. of Horti., 33: 2944.

El-Salhy, A.M.; K.I.A. Amen; A.A.B. Masoud and A.A. Eman Abozed. 2011. Response of Ruby seedless and Red Roomy grapevines to application of some bio-fertilizers. Assiut J. Agric. Sci., 41 (5): 125142.

El-Salhy, A.M.; Kamelia, A. Amin; E.A. Hassan and Shimaa H. Gaber. 2013. The effect of different sources of nitrogen and potassium fertilization on growth and fruiting of Thompson seedless grapevines. $1^{\text {st }}$ Assiut St. Assiut Inter. Conf. Hort., pp. 116-132.

El-Shenawy, F.E. and T.A. Fayed. 2005. Evaluation of the convential to organic and bio-fertilizers on Cirmson seedless grapevine in comparison with chemical fertilization. 2Yield and fruit quality. Egypt. J. Appl. Sci., 20 (1): 212-225.

Gaur, A.C.; K.P. Ostwal and R.S. Mathur 1980. Save superphosphate 
by using phosphor- bacteria. Kheti, 32: 23-35.

Gomez, K.A. and A.A. Gomez. 1984. Statistical Procedures for Agricultural Research, 2nd Ed. Willy, New York.

Hegab, M.M.; M.I.F. Fawiz and N.E. Ashour. 2010. Effect of different yeast doses and time of application on growth, yield and quality of Ruby seedless grapevines. Minia J. of Agric. Res. \& Develop., 30 (1): 231-242.

Kannaiyan, S. 2002. Biotechnology of bio-fertilizers Alpha Sci. Inter Ltd. P.O. Box 4067 Pang Bourne R. 68. M.K. pp: 1-275.

Keller, M. 2005. Nitrogen-fielded for of wine quality. Practical winery and vineyard magazine 58D Paul Drive, San Rafael, CA 94903-1534 (9) issue.

M.A.L.R. 2014: Ministry of Agriculture and Land Reclamation Economic Affairs Sector Bull., Agric. Statistics.

Masoud, A.A.B. 2012. Effect of organic and bio nitrogen fertilization on growth, nutrient status and fruiting of Flame seedless and Ruby seedless grapevines. J. of Agric. and Biolog. Sci., 8 (2): 83-91.

Mengel, K. And E.A. Kirkby. 2001. Principles of Plant Nutritioin. $5^{\text {th }}$ rev. ed, Kluwer Academic Publishers (United States), ISBN10: 1402000081 .

Mostafa, R.A.A. 2008. Effect of bio and organic nitrogen fertilization and elemental sulpher application on growth, yield and fruit quality of Flame seedless grapevines Assiut J. of Agric. Sci., 39(1): 79-96.

Myint, C.C. 1999. EM nature forming technology, research and extension activities in Myammar. $6^{\text {th }}$ International Conference on Kyusei Nature Farming Pretoria, Pretoria,
South Africa, 28-30 October, 1999.

Nijjar, G.S. 1985. Nutrition of Fruit Trees. Mrs. Usha Raji Kumar, Kilyani, New Delhia, India, 206234.

Rabie, A.M. and A.A. Negm. 2012. Effect of some organic treatments on some grapevine cultivars. Ph.D. Thesis, Fac. of Agric., Cairo Univ., Egypt.

Ram Rao, D.M.; J. Kodandaramaiah; M.P. Reddy; R.S. Katiyar and V.K. Rahmathulla. 2007. Effect of AM fungi and bacterial biofertilizers on mulberry lef quality and silkworm cocoon characters under semiarid conditions. Caspian J. Env. Sci., 5 (2): 111-117.

Sahrawat, K.L. 1979. Nitrogen losses in rice soils. Frt. News, 24: 38-48.

Shimbio, S.; Z.W. Zhang; T. Watanable; H. Nakatsuka; N. MatsudaInoguch; K. Higashikawa and M. Ikeda. 2001. Cadmium and lead contents in rice and other cereal products in Japan in 1998-2000. Sci. of Total Environ. 281: 165174.

Steel, R.G.D. and J.H. Torrie 1980. Principles and procedures of statistics: Biometrical approach Mc-Grow Hill Book company (2nd Ed) N.Y, pp: 631.

Suba Rao, N.S. 1984. Bio-fertilizers in Agriculture Oxford. IBH Company. New Delhi.

Verna, L.N. 1999. Role of biotechnology in supplying plant nutrients in the vineties. Fertilizer news., 35: 8797.

Wilde, S.A.; R.B. Corey; J.G. Lyer and G.K. Voigt. 1985. Soil and plant analysis for tree cultivars. Oxford, IBH, New Delhi, India, pp: 94105. 


$$
\text { دور التسميد الحيوي في تحسين نمو و إثمار كروم العنب الطومسون اللابذري }
$$

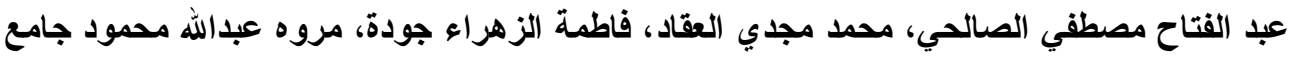

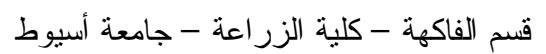

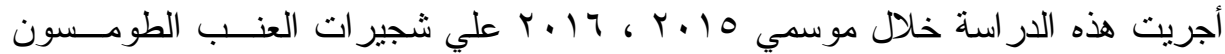

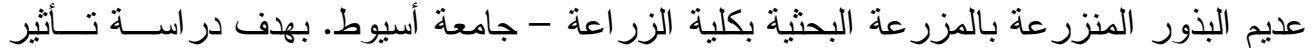

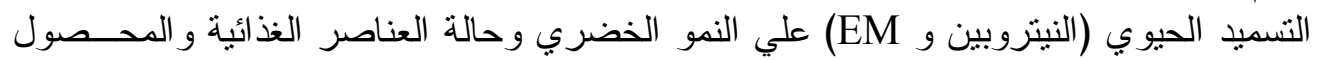
وخصائص العناقيد و الحبات.

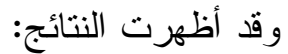

- أدي استخدام التسميد في الصورة الثنائية (معدني + حيوي) إلي زيادة مؤكدة فــي وزن التوري

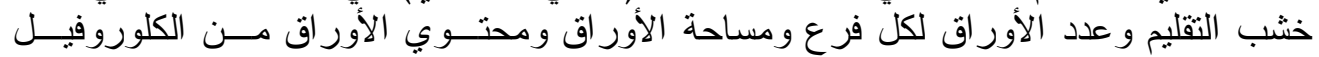
و عناصر النيتروجين و الفوسفور و البوتاسيوم مقارنة بإستخدام التسميد في الصورة التورة المعدنية فقط. -سبب إستخدام التسميد في الصورة المركبة تحسين صفات العنقــود و الثــــار مقارنـــة بالتسميد المعدني فقط.

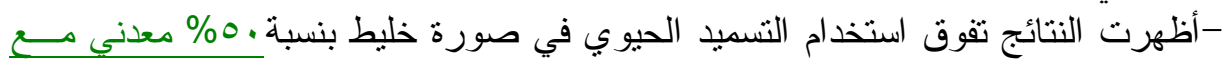

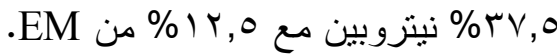

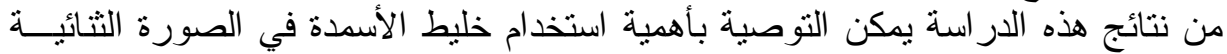

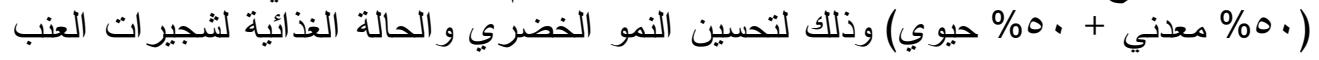

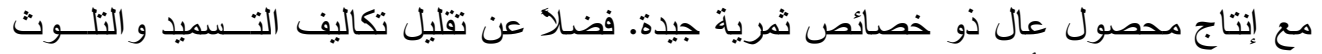
البيئي الناشئ عن الأسمدة المعدنية. 